\title{
Controlling the Boundaries of Morality: The History and Powers of Ayelala Deity
}

\author{
Oluwafunminiyi Raheem \\ Adeyemi College of Education Ondo, Nigeria \\ creativitysells@gmail.com \\ Mike Famiyesin \\ Adeyemi College of Education Ondo, Nigeria \\ mikefamiyesin@yahoo.com
}

\begin{abstract}
The worship of deities has always been a major religious preoccupation among the Yoruba. Among these deities is Ayelala, a water goddess, who is not only worshiped with pomp and pageantry but also highly revered and respected for its judicial powers. As a deity of retribution and justice, Ayelala is believed to possess great powers which she uses against varying forms of social vice, such as armed robbery, sexual offences, and witchcraft to mention a few. Ayelala is reputed for seeking vengeance when the offender has forgotten her or his crime, and strikes her victims by inflicting on them bodily swelling and in few cases, dryness. Such is Ayelala's overwhelming power and potency that the deity seeks to control the boundaries of morality and at the same time forms a major bulwark against societal impropriety.

Our article examines the history of Ayelala, being one of the popular deities worshipped in coastal Yorubaland. It also interrogates how the deity's power stems from the importance of boundaries and difference, insofar as these warrant the strict obedience of individuals, their families and the society as a whole to the prevailing set of moral demands. The article contends that beyond the narratives of power, potency and retribution, Ayelala's role as an arbiter of justice underscores the importance of civic values held within communities where the deity is worshipped - which are also values that undergird intergroup relations. Though Ayelala worship is pervasive among the llaje, Ikale and ljaw-Apoi
\end{abstract}


communities of Ondo state, Nigeria, the deity is also linked with other neighboring and distant communities which highlight the unifying tendencies of a common religion and deity belief among different sub-ethnic groups.

\section{Introduction}

For the Yoruba, Olodumare, the Supreme Being, is viewed as superior to, and distinct from, other deities, though they express their worship and dependence on the latter. Between man and deity, there exist strong links which helps to build a relationship where "responses of worship and offering of sacrifices to the divinities" are aptly discharged. ${ }^{1}$ This relationship creates an enabling environment for law and order to reign even as people shun acts that could result in colossal penalties from the deity. ${ }^{2}$ It is here that the deity, Ayelala comes into play. Ayelala's powers are so great that little acts of immorality invite instant fury and consequences. Adherents of the goddess usually call for caution and restraint around her because the binding forces that birthed her demand openness and truth. Anything short of these is an invitation to disastrous retribution by the deity.

Deities are often indigenous or peculiar to a locality, ${ }^{3}$ but become known or popular in other localities for various reasons. By so doing, deities play an influential role in deepening intergroup relations. Among the factors that reinforced the roles of deities in intergroup relations was migration. Migration was a common practice in Yoruba history, and it was often linked to aspirations for a better life, whether in terms of search for better dwellings, escape from war or disease among others. This trend supported mutual borrowing and the dispersal of practices across a wide region. Similarly, when mobile communities or people settled in their new abodes, they often introduced facets of social or religious institutions from other places, which reinforced the integrative role played by these institutions among the Yoruba. For example, many Òrìnà deities linked to Ile-Ife and Oyo spread to other parts of Yorubaland, especially in the aftermath of Oyo's collapse. Conversely, many communities worshipped deities that were not original to the community.

Our study is centered mainly on Ilaje and Ese-Ode Local Government Areas (LGAs), two coastal communities in Ondo State, and Okitipupa LGA, also in

1. J. A. Olarenwaju, "The Relationship between People and Supernatural Beings in Yoruba Traditional Culture," Journal of Adventist Mission Studies, 5.2 (2009): 45.

2. Ibid.

3. N. A. Fadipe, The Sociology of the Yoruba (Ibadan: Ibadan University Press, 1970), 261. 
Ondo State. In addition, we focus on Ogbere in Ijebu East LGA, Ogun State and Oluku in Ovia North East LGA, Edo State. The Ilaje (Ilaje LGA), a distinct linguistic group of the Yoruba, claim their original ancestral home from Ile-Ife from where they migrated to their present location in Ilaje LGA, Ondo State. The riverine Ijaw-Apoi (different from the Ijaw Furupagha and Ijaw-Arogbo stock in the same area), a distinct ethnic group whose members, however, speak Yoruba, are bounded to the West by the Ilaje, the North by the Ikale, the Ijaw-Arogbo to the South and Furupagha to the East. This group traces their origin to a migration from the central Niger Delta, Brass Division of present-day Rivers State. They presently populate Ese-Ode LGA in Ondo State. The Ikale, also a Yoruba sub-group, share boundaries with the Ilaje, Ijaw-Apoi and Ijaw-Arogbo to the south, Odigbo LGA to the West and North and parts of Ogun State. They occupy present-day Okitipupa and Irele LGAs. Ogbere, occupied by the Ijebu, is bounded to the North by Ijebu North LGA, in the East by Odigbo LGA of Ondo State, North and West by Ijebu-Ode and Odogbolu LGAs, South and Southwest to the Lekki Lagoon and Epe LGA of Lagos State and to the Southeast by Ogun Waterside LGA. Oluku is a small town in Ovia North East LGA close to Benin, Edo State and major cities such as Owo and Akure. The LGA has fifteen towns and about fifty villages occupied by the Edo speaking people who are said to share the same origin with Bini and Yoruba.

Typical of many gods in Yorubaland, Ayelala is not only worshiped with pomp and pageantry but also highly revered and respected by its worshippers. ${ }^{4}$ Ayelala is linked to conflict resolution and retribution against societal impropriety. Her role underscores the importance of civic values held within communities where she is deified, which are also values that underpin intergroup relations. One factor that highlights the importance of Ayelala in intergroup relations is that unlike other deities, whose functions are often adapted when they are adopted by a new community to suit local needs, Ayelala worship does not permit significant modification or interpolation. Unlike the manifestations of other deities, which can differ considerably between settlements, Ayelala's manifestations in all coastal communities where she is worshipped are very similar. Our study therefore contends that beyond the narratives of power, potency and retribution associated with her, Ayelala's worship, which centers on communal relations, underscores the importance of civic values held within communities where the deity is worshipped, which act as a template for intergroup relationships.

4. We found this practice of "pomp and pageantry" among the deity's worshippers in Oluku, headquarters of Ayelala shrine in Ovia North East LGA, Edo State. 


\section{The Origin of Ayelala}

A body of literature exists on what constitutes the historical foundation of Ayelala. ${ }^{5}$ These studies trace the deification of Ayelala back to a war between two neighboring Yoruba coastal communities in connection over an adulterous relationship. However, despite the agreement in the literature on Ayelala's historical foundation, there exist conflicting oral traditions. Before we examine these, it is important to state that all agree that Ayelala was a human woman who was presented as a "substitutionary sacrifice" as part of an agreement to end a communal war. ${ }^{6}$

Most worshippers agree that that an Ijaw-Apoi commoner called Keko had carnal knowledge with the wife of one Temetan, an Ilaje Chief. Once Temetan became aware of the betrayal, Keko fled to Igbobini, a locality in present-day Ese-Odo LGA inhabited by the Ijaw-Apoi, in an attempt to avoid being reprimanded. He sought sanctuary at the Oborowe shrine (popular with the IjawApoi), where he pleaded with the people to save his life. Being a commoner, his action was punishable by death according to the law. ${ }^{7} \mathrm{He}$ was nevertheless asked to provide a carton of gin after which he was shielded from his wouldbe-captors. Since the Ijaw-Apoi refused to hand over Keko, a long battle raged between the two communities. Following the devastation brought by the war, a man named Idiogbe, ${ }^{8}$ a native of Aboto in present-day Ilaje LGA, ${ }^{9}$ but living among the Ijaw-Apoi, asked his Ijaw friend, Agbeleki to help him intervene in the crisis. While Idiogbe met with the Ilaje people, Agbeleki appealed to the Ijaw-Apoi to sheathe their swords. Eventually, both parties agreed to keep the peace on the condition that Keko would be replaced by another human being for a sacrifice.

In many pre-colonial societies, especially among the Yoruba, it was not uncommon to use humans for sacrifice to end a calamity, revoke a deity's punish-

5. See, for instance, O. O. Fafeyiwa, The History of Ayelala (Ibadan: Methodist Church, 2003); J. O. Awolalu, "Ayelala: A Guardian of Social Morality," Orita - Ibadan Journal of Religious Studies, 11.2 (1968); S. Ayelala Omosule, "The Truth of the Matter", Nigerian Tribune, June 4, 1994, 1-2 and J.O. Awolalu, Yoruba Beliefs and Sacrificial Rites (London: Longman, 1979), 41-45.

6. J. O. Awolalu, and P. A. Dopamu, West African Traditional Religion (Ibadan: Onibonoje Press and Book Industries, 1979), 90.

7. Ibid.

8. The person of Idiogbe is not clear but we tend to believe he was the renowned Chief among the Aboto whose position or title changed overtime, first as Oloja of Aboto, and more recently, Alaboto of Aboto.

9. Aboto is known in recent times as Olokola-Aboto. However, in Ilaje LGA, it links the coastal areas of both Ondo and Ogun States. 
ment or to appease the gods. ${ }^{10}$ In the case of both the Ilaje and Ijaw-Apoi, this condition may have sufficed as part of an everyday ritual practice. Other sacrificial items included three yards of white cloth, five bags of cowries, three alligator peppers, three red parrot feathers, several lobes of Kolanut, three native white chalk and three needles. ${ }^{11}$ Except for few appendages in recent times, these constitute the sacrificial items or materials used in the worship, consultation or appeasement of Ayelala till date.

The agreement between the two warring parties warranted a search for a suitable human for the sacrifice. It was rare, however, for 'normal' and freeborn citizens to be used for sacrifice as most of victims of human sacrifice were condemned criminals or slaves, but humans of 'unusual' form or nature such as twins, the hunchbacked, or dwarfs were also sacrificed. Several explanations for the choice of Ayelala as the offered victim of sacrifice exist. First, Ayelala herself was said to have devoutly worshipped nine gods and goddesses in her life time. ${ }^{12}$ Perhaps her spiritual proximity to these gods singled her out for sacrifice to serve as an "ambassador" that would "replenish the people... and carry their petitions to the higher power". ${ }^{13}$ Second, as noted above, Ayelala may have been picked because she was not a freeborn within the society she grew up in, even though it is said she married and bore children among the Ilaje. ${ }^{14}$ As we shall see below, she may have been a slave, or simply a stranger or outsider and so may have been regarded as an appropriate choice for the sacrifice. According to Johnson, the Ijesa, in their etymological rendition, are known as 'İje Òrìnà,' meaning 'the food of the gods. ${ }^{15}$ Born by an Ilesa father, it is possible that Ayelala was selected based on the idea that she was a member of the 'sacrificial stock' known across the Yoruba country. Third, some traditions claim that Ayelala had come into physical contact with the male-only Orò cult, which is forbidden to women, and as a consequence was automatically condemned to become an object of sacrifice. ${ }^{16}$ 87 .

10. J. O. Awolalu, "Yoruba Sacrificial Practices," Journal of Religion in Africa, 5.2 (1973):

11. Fafeyiwa, The History of Ayelala, 15.

12. Ibid, 3; Awolalu, Yoruba Beliefs and Sacrificial Rites, 41-45.

13. E. B. Idowu, Olodumare: God in Yoruba Belief (London: Longmans, 1962), 110.

14. Ayelala Omosule, "The Truth of the Matter," 2.

15. S. Johnson, History of the Yorubas from the Earliest Times to the Beginning of the British Protectorate (Lagos: CSS Ltd, 1921), 12.

16. The uncertainty of her status within the Ilaje-Ijaw-Apoi communities is complicated by another tradition given by a devotee who maintained Ayelala was a slave sold by the owner at Igomola, Erinje, to the parties who needed her for a quick sacrifice to end the communal war in the area. 
There are also conflicting traditions about the manner of sacrifice. While one tradition affirmed she was buried alive with both her neck and head exposed above the earth, another claimed she was beheaded and consequently buried. ${ }^{17}$ In any case, facing the pangs of death, the sacrificial victim uttered the words, "Ayelala O!", an expression in Ilaje dialect meaning "the world is incomprehensible," "mysterious," or "wicked." The exclamation presupposes that she was being sacrificed or punished for the crime committed by someone else. ${ }^{18}$ The long communal strife between the two parties soon ended and the name, Ayelala was later adopted in reference to the deity.

The representation of Ayelala as a slave and/or stranger, and as the victim of human sacrifice, underscores the link between slavery and trade, on the one hand, and human sacrifice, on the other hand. These practices are associated with the production of social outsiders, and point to the boundaries between desirable and non-desirable forms of existence. Beyond this, Ayelala is associated with the crime of adultery as well as the transgression of the gendered order of the Orò cult, i.e. with the transgression of marital and sexual boundaries. The deity's association with social boundaries is further confirmed by the fact that she is linked to the end of intergroup conflict, having been sacrificed at Ita Ayelala, a junction between the Ugbo and Mahin kingdoms in present-day Ondo State. Even her name, Ayelala, referring to lack of comprehensibility, suggests that the deity's powers are drawn from the blurring of categories or the crossing of boundaries.

\section{Ayelala's association with the outside or Atlantic world}

Ayelala's association with the crossing of boundaries also recalls with the region's participation in the Atlantic trade in ways that go beyond her designation as a slave. There are some interesting traditions regarding Ayelala's name before her deification. While Awolalu could not provide the original name of Ayelala because informants kept it a "ritual top secret", ${ }^{19}$ the names given to us by respondents and other informants confirm that there is no agreement on Ayelala's name. ${ }^{20}$ Quoting an Ikale chief familiar with the worship of Ayelala, Fafeyiwa's seminal work on Ayelala explains that the deity was originally referred to as Lala and bore the Christian name, Ruth before given out for sacri-

17. Fafeyiwa, The History of Ayelala, 3.

18. Awolalu, Yoruba Beliefs and Sacrificial Rites, 42.

19. Ibid, 41.

20. Chief Pius Otedo, a native doctor in Ikorodu area of Lagos State claimed she was originally called Ruwaghan. See S. Raji, “True Confession: Girl Kills Son as Woman Wrecks Business," The Nigerian Observer, May 14, 2011. 
fice. ${ }^{21}$ As the existence of Ayelala predates the colonial period, the references to her bearing a Christian name are interesting. Her name might reflect the presence of Portuguese in the Ilaje area, which dates back to the early $16^{\text {th }}$ century. ${ }^{22}$ Early Portuguese contact with the Ilaje and other riverine peoples (the Benin, the Escravos, the Forcados and the Ramos as the Portuguese called it), may have led to the diffusion of names and practices linked to (Catholic) Christianity. ${ }^{23}$

A different version mentioning the name Ruth is offered in the same work by Fafeyiwa by another source, who claims that Ayelala was locally called Ami$n o$ while her half-sister was known as Ruth. ${ }^{24}$ Again, the name Amino may point to Portuguese origins the river Miño (or Minno), which originates in the Spanish Sierra de Meira, follows the boundary between Spain and northern Portugal. Derived from the Latin word minius, meaning red, cinnabar or vermillion, the name Miño essentially refers to the "red river". It is interesting that the colors red and white, standing for, among other things, blood and water, are clearly identified as Ayelala's colors. However, there are also other understandings of what Amino means. Alhaji Dauda, a popular Ayelala chief priest interviewed in Ogbere, explained that,

[Amino] was not the local name given to Ayelala. Amino is referred to as the vice squad of all Ayelala shrine or Umale. This is represented by a flag which is usually hoisted outside the shrine. What it does is to follow all evil doers (witches, wizards etc.) with the sole aim of apprehending anyone who intends to outwit it. ${ }^{25}$

Again, there is no precise agreement on what these flags, or more accurately poles wrapped with white and red cloth, stand for. Aside claims in Ogbere that these mounted poles served as Ayelala's vice squad against evil doers, adherents in the Oluku and Ikale areas claimed the colors of the flagpoles represent the purity required of worshippers by the deity. ${ }^{26}$

Returning to Ayelala's name before her sacrifice Otunba Johnson Gbemisola, an Ifa Priest living in Ondo, affirmed that she was referred by the Ilaje as

21. Fafeyiwa, The History of Ayelala, 2.

22. A.F.C. Ryder, "An Early Portuguese Trading Voyage to the Forcados River," Journal of the Historical Society of Nigeria, 1.4 (1959): 294.

23. See G. Ikuejube, Ilaje: The Yoruba Fishing People of the Niger-Delta (Novec'kol Printer and Publisher, 2005), 9.

24. Fafeyiwa, The History of Ayelala, 4.

25. Interview with Alhaji Dauda Musa, Ayelala chief priest, Ogbere, Ijebu-Ode, 27 September, 2016. Other shrines we visited claimed this long wood or rod hosted merely a flag signifying the presence or extension of Ayelala shrine in a community.

26. See also, Awolalu, Yoruba Beliefs and Sacrificial Rites, 45. 
'Ono'ke', a local form of 'Ara Oke' (i.e. a person from upcountry or abroad). This label, he claimed, was simply pointing at Ayelala's origin from Ilesa in present-day Ilesa LGA, Osun State. ${ }^{27}$ However, there also exist some differences in the traditions about Ayelala's origin. While some of our respondents in Ikale claimed that she was a slave from Igomola, Erinje (in Okitipupa LGA), respondents in Ogbere, Oluku and those from Ilaje and Ijaw-Apoi pointed to an Ilaje ancestry close to the same area. Another version talked of a distant Yoruba paternal descent from Ilesa. ${ }^{28}$ This version affirms that Ayelala's father, a trader from Ilesa, had travelled to Ikaleland to sell a local fabric known as Kitike, and had a child, the woman who would later become Ayelala, with an Ikale woman.${ }^{29}$ Contrary to Fafeyiwa's claims, Awolalu notes that Ayelala was originally from Ekiti Division, from where she was brought to Kisoso, a village in Okitipupa. ${ }^{30}$ We assume here that Ekiti could also mean 'Ara Oke', i.e. it could simply indicate a person from abroad as pointed above.

Ayelala's sacrifice was carried out by two individuals representing the groups involved in the dispute. In the process of sacrificing her, the Ilaje representative, who alongside his Ijaw-Apoi counterpart had boarded a boat to Ita Ayelala together, jumped out of the boat first, holding onto her right hand, while the Ijaw-Apoi representative followed suit, holding the left hand. Thereafter, a whole Kolanut was split by both representative and prayers in between said after which the lobes were thrown upon the ground. ${ }^{31}$ The second act made it incumbent on Ayelala to offer prayers for those who sacrificed her, reflecting the traditional understanding that the cause for which a victim was sacrificed would succeed. ${ }^{32}$ Once Ayelala was deified, she acted instantly by killing anyone who defied the covenant. ${ }^{33}$ Experiences believed to be Ayelala's instantaneous judgment against the breach of the covenant impressed fear among the people and thus, prepared the way for social order and justice. ${ }^{34}$

As in the original act of sacrifice, Kolanut and gin or Ògógóró are needed to appease Ayelala. Kolanut can also be used for consultation with the deity (div-

27. Interview with Otunba Johnson Gbemisola, Ifa Priest, No. 8, Ifelodun Street, Off Rainbow Road, Ondo. October 14, 2016.

28. Fafeyiwa, The History of Ayelala, 1, 4; Interview with Otunba Johnson Gbemisola. October 14, 2016.

29. Fafeyiwa, The History of Ayelala, 4.

30. Awolalu, Yoruba Beliefs and Sacrificial Rites, 41.

31. Fafeyiwa, The History of Ayelala, 27.

32. Awolalu, Yoruba Beliefs and Sacrificial Rites, 42.

33. Fafeyiwa relates an instance where an Ijaw man was instantly put to death for breach of the covenant. See Fafeyiwa, The History of Ayelala, p. 6.

34. Ibid. 
ination). ${ }^{35}$ While Kolanut is widely used for such purposes in Yorubaland, the use of gin is interesting, because Ayelala was not known before her sacrifice to have consumed any alcohol. Moreover, the distillation of alcohol is generally assumed to have a relatively recent history in coastal Nigeria that began with the importation of European trade spirits. ${ }^{36}$ Again, the use of gin may point to the presence of Europeans in this coastal area, and perhaps their indirect involvement on the events surrounding the emergence of the deity. As a goddess, part of Ayelala's Oríki (praise-name) refers to her as 'A jí fotí wè b'Óyìibó,' meaning 'one who early in the day bathes in gin like the white man. ${ }^{37}$

As Ayelala is worshipped using the local dry gin, it is likely that its use also spread as a result of Ayelala worship. For example, though not originally indigenous to the Ikale, their use of the dry gin to appease Ayelala was evidently adopted from both the Ilaje and Ijaw-Apoi which the latter produced and did form part of their articles of trade. As an important drink that accompanied social events and religious gatherings, it turned out to be a very important appropriation in the deification of Ayelala. ${ }^{38}$ Ogen notes that the socio-religious life of the Ikale would not be complete without it. ${ }^{39}$ Following the Ilaje, Ijaw-Apoi and Ikale, other coastal groups who deify Ayelala appear to also use gin or Ògógóró today.

As one of the materials used in appeasing Ayelala, gin remains a constant reminder of the deity's association with boundaries. Both the qualities of gin and its origin from the outside meant that it is often credited with the ability to transcend the boundaries between this world and the invisible one. The substitution of imported gin with Ògógóró adds another layer to the motif of transcendence, because the production of local gin or Ògógóró often takes place outside of formal legal provisions. ${ }^{40}$ Yet as the production of Ògógóró is not seen as immoral as long as it is produced properly, its use points to the fluid

35. Interview with High Priest Agba Oye Akinbuwa, Idepe, Okitipupa, August 27, 2016.

36. S. Heap, "Those that are Cooking the Gins': the Business of Ogogoro in Nigeria during the 1930s," Contemporary Drug Problems, 35.4 (2008): 573-610.

37. A.F. Fatumbi, Oriki Egun: Praising the Ancestors, [n.p], 2013, 11. See also, Awolalu, Yoruba Beliefs and Sacrificial Rites, 101.

38. J.A. Akinbi, "The Social, Economic and Political Relationship between the Ikale and Ilaje in Okitipupa Area of Ondo State from about 1884 to the 1950s," B.A. Essay, University of Lagos, 1983, 39, 46.

39. O. J. Ogen, "The Ikale of South-Eastern Yorubaland, 1500-1900: A Study in Ethnic Identity and Traditional Economy," PhD Diss., University of Lagos, 2005, 330.

40. S. Heap, "Living on the Proceeds of a Grog Shop: Liquor Revenue in Nigeria," in D.F. Bryceson, ed., Alcohol in Africa: Mixing Business, Pleasure and Politics (Portsmouth: Heinemann, 2002), 139-159. 
boundary between what is legal and what is illegal, and between a 'deeper' morality and the rule of law.

Despite the differences in the explanations surrounding Ayelala's history, it seems that her power derives not primarily from her association with the outside world, but from her existence both as an outsider and an insider, and as a consumer of commodities, such as gin or Ògógóró, that cannot be clearly categorized. It is almost as if Ayelala draws on the power of ambivalence to ensure the maintenance of boundaries among her followers.

\section{Ayelala's powers of punishment and protection}

The circumstances that surrounded Ayelala's original sacrifice are understood as a covenant between the deity and the communities of her followers to obey and uphold social and gendered norms. For those who worship Ayelala, they must ensure to have the highest attainment of cleanliness. Adherents must not only be physically clean but morally upright. In the context of Ayelala worship, impurity is constituted by (recent) sexual intercourse or the consumption of particular foods, such as palm oil and anything prepared with palm oil, cassava, water yam, pounded yam, and sugar cane. But most importantly, Ayelala abhors a devotee who harbors evil intentions. Worshippers believe that Ayelala is quick to react when her requirements are flouted, and often priests warn the public accordingly.

Requirements for purity also center on the control of female bodies. As women are deemed unclean following their monthly cycle, they are not only forbidden from the shrine but are usually excluded from occupying any priestly position within the cult. At Oluku, Ikale, Ogbere and Ijaw-Apoi communities, all the shrines we encountered were manned by male priests. Moreover, at Oluku, a big sign post placed just outside the entrance of the shrine indicates that women are forbidden from entering into the shrine while menstruating. This instruction is also conveyed by word of mouth by male shrine devotees to all women waiting to have an audience with the chief priest.

In general, Ayelala's powers are linked to her life and sacrifice. As mentioned above, Ayelala causes body swelling, or sometimes dryness, in its victims, which is usually manifested in stomach protrusion, with other parts of the body turning grey. The bodily swelling, understood to be caused by water, links to Ayelala's history, because Ayelala was sacrificed and buried close to a junction of two rivers, now called Ita Ayelala River (in Ilaje). The shrine devoted to Ayelala's worship is located near Igbokoda in Ilaje LGA. Worshippers believe this was the area where Ayelala, once sacrificed, transformed into water. The water drawn from this place is commonly used to consult Ayelala, and 
it is often taken to other places for this reason. This particular water is also believed to be, or represent, the liquid extracted from the body of Ayelala's victims which, among other purposes, is also used to worship Ayelala and domicile other Ayelala shrines elsewhere. ${ }^{41}$ It is why Ayelala can be consulted anywhere and responds quickly, especially where there is access to free-flowing water or availability of this particular water drawn from Ita Ayelala River.

In addition to the dispensation of justice, Ayelala is also sought after for protection. ${ }^{42}$ This is done by setting up a simple shrine in the home to serve as security and to help uncover the enemy's plot. ${ }^{43}$ A British colonial officer explains this in the light of Ayelala's protective role:

Ayelala is a good juju and protects the town, and it has the special power of detecting criminals, witches, and the users of bad medicine... If a person leaves any property in the bush and wishes Ayelala to protect it, he will take a cowry from the shrine and tie it to the load and if a thief interferes with it he will swell up and die. In the same way the entrance to a farm will often be protected by an Ayelala cowry hung on a string. ${ }^{44}$

Despite Ayelala's prime position as an arbiter of justice, instances abound where her powers are inhibited by those who fear her punishment. This usually occurs when someone fortifies themselves with materials or objects Ayelala forbids. In such cases, Ayelala is often believed to call for help from other divinities. Hence, punishment could come in form of thunder [lightning] through her ally Sàngó, or by inflicting measles or small pox through Sòpònnó. ${ }^{45}$ It is unusual for lightning to strike a human according to the Yoruba belief system, but then when it does; it is presumed the victim must have committed a heinous crime. ${ }^{46}$ Thus even when people suffer or die in ways that

41. We are grateful to Dr J.K. Odetayo of the Religious Studies Department, Adeyemi College of Education, Ondo for this vital information.

42. It was recorded by the Ijebu Province resident officer that the Elero of Ijebu, a titled chief in the Ilaje Area in May 1947, claimed to be under the protection of Ayelala, cited in T.A. Oladimeji, "The Spread of Islam in Nigeria: The Case of Ijebu Land," in S.G.A. Onibere and M. P. Adogbo, eds., Selected Themes in the Study of Religions in Nigeria (Lagos: Malthouse, 2010), 113.

43. Fafeyiwa, The History of Ayelala, 10.

44. National Archives Ibadan (NAI). Ikale Assessment Report, CSO 24/4/30030, Vol. 1, B.J.A. Mathews 1932, 149-150.

45. Interview with High Chief Eniola Lijoka, Otiogunbowajoye of Igodan-Lisa, Okitipupa. August 27, 2016.

46. J. O. Awolalu, "Sin and its Removal in African Traditional Religion," Journal of the American Academy of Religion, 44.2 (1976): 286-287. 
point to other deities, many people in the coastal areas attribute the punishments indirectly to Ayelala. ${ }^{47}$

Unlike in some belief systems where sin is repeatedly forgiven and judgment reserved for the afterlife, grave offenders against Ayelala are not forgiven. ${ }^{48} \mathrm{~A}$ victim who commits a light offence and confesses is quickly relieved of his body swelling through regular urination. An unlucky victim, however, is struck by death and the body never allowed to be given a befitting burial by the family. ${ }^{49}$ Moreover, victims face punishment and judgment while they are ill, both in the form of abuse and bodily punishment while alive. Rather than weep, mourn or show remorse, the injured party is required to congratulate the families of Ayelala's victims for helping to get rid of an evil-doer. ${ }^{50}$ If the victims die, their corpses are thrown into a wild part of the forest to rot away or taken by the chief priest to the Ayelala shrine where it is used for secret purposes. ${ }^{51}$

We learnt of an incident that illustrates Ayelala's power even in contemporary society. One respondent told us of a death caused by Ayelala within her family, where the victim's body was buried secretly. Because the brother of the victim was a pastor who did not believe that his sibling had been struck by what he believed was a non-existent deity, and he took the victim's body from Lagos for burial in their village in Ikale. By the third day, the victim's fresh body had re-emerged from the ground. Beyond the fact that the secret of this shameful death had now been exposed, the pastor was convinced of Ayelala's powers and agreed to hand over the brother's body to the chief priest. ${ }^{52}$

It is interesting to note that the personal wealth or belongings of a victim of Ayelala must not be used by close family relations, extended or distant, or even among friends. ${ }^{53}$ This is because Ayelala views all the victim's possessions as part of the punishment that must be meted out for breaching the communal covenant that formed the genesis of Ayelala. An instance was narrated to us at Idepe, a locality in Ikale where Ayelala worship is prominent. Here, the mother

47. Interview with Otunba Johnson Gbemisola. October 14, 2016.

48. According to Islamic teachings, for example, it is believed that God forgives as he pleases and would always do so for those who show genuine commitment to repentance so long as they stay away from sinful acts. See T. Govier, Forgiveness and Revenge (London: Routledge, 2002), 161.

49. Fafeyiwa, The History of Ayelala, 24.

50. Awolalu and Dopamu, West African Traditional Religion, 91.

51. Fafeyiwa's apt description suffices here: "The corpse is treated with disrespect by the priest ... beaten with hard wood [while] the priests dance and sing round it and dragging it on the ground in the process of worship. Later, the corpse is tied with bamboo poles and taken to the bush for burial." (Fafeyiwa, The History of Ayelala, 19).

52. Interview with Mrs Lola Aderibigbe, hairstylist, No. 10, Iwajowa Street, Opposite Adeyemi College, Ondo. October 19, 2016.

53. Awolalu and Dopamu, West African Traditional Religion, 254. 
of a victim struck by Ayelala fell very ill some weeks after her daughter's death. Having consulted the traditional priests, it was learnt she had been inflicted by Ayelala for using her daughter's bowl to soak pupuru (cassava) flakes before consumption. While there are occasions where the possessions of a victim can be used after some time, usually determined by the Ayelala priest, other instances abound where despite consultations with the priests, this is not possible. In such cases, the priest takes full possession of all the victim's belongings after which they are dumped into the bush. ${ }^{54}$

Near the entrance of the Ayelala shrine at Oluku, we encountered a handful of abandoned properties including foams and mattresses, television sets, video players, bowls, buckets, clothing, shoes, and even motorbikes apparently appropriated by the Alayelala or chief priest, as part of the properties owned by victims struck by the deity. It should be noted that for those belongings Ayelala allows to be taken back and used, compensation must be paid to the chief priest, after which spiritual cleansing takes place. ${ }^{55}$ Originally a small payment, fees have increased in recent times, although people suggested that some priests willfully appropriate victims' properties. However, greater problems are caused by the fact that Ayelala can insist that houses or land belonging to the victim cannot be used. Alhaji Musa explained,

The properties belonging to Ayelala's victims do not only perish but appear more as a problem because it cannot be released to anyone since the victim is now seen as a deadly deity. Ayelala would never allow the use of a victim's property unless propitiation is fully and properly carried out. ${ }^{56}$

As the force of Ayelala's anger is understood not only to afflict individuals but also their families, the family of a victim must as a necessity seek to appease Ayelala to avoid further calamity among its members. As mentioned earlier, a victim of Ayelala is neither mourned nor treated with such dignity or respect accorded the dead in the society. Indeed, the community often unites in pillorying not only the memory of the victim but also in stigmatizing the victim's family at large. Two of such families were shown to us in the Ilaje and Ikale communities, respectively. The unpleasantness of such ostracism ensures

54. Awolalu and Dopamu consider the death of Ayelala's victims as a "bad death" which do not benefit from the devotion given to ancestors and are "not discussed beyond the point of the necessity to dispose of them [victims' body] as hurriedly as possible."

55. Interview with High Chief Aiyegbe Lijoka, Bobajiroro of Igodan-Lisa. August 28, 2016.

56. Interview with Alhaji Dauda Musa, Ayelala chief priest, Ogbere, Ijebu-Ode. September 27, 2016. Other shrines we visited claimed this long wood or rod hosted merely a flag signifying the presence or extension of Ayelala shrine in a community. 
that the vast majority of people within communities where Ayelala is worshiped live above board.

\section{Ayelala and the Dynamics of Intergroup Relations}

Ayelala's powerful control over personal morality also affected inter-group relations among coastal Yoruba communities. As pointed out earlier, it was not until the conscientious intervention of Agbeleki and Idiogbe that the Ilaje and Ijaw-Apoi conflict came to an end. We assume that before the ultimate sacrifice of Ayelala, or most likely after, both groups had set the basis for a modus vivendi which was crucial for their ensuing survival. ${ }^{57}$ It is possible that through their encounter with each other, which led to the creation of Ayelala, the two groups found a way to co-exist peacefully through the control of personal morality.

In the mythical history surrounding Ayelala, Agbeleki and Idiogbe's reconciliatory efforts were rewarded. They were soon to be elevated as the first Ayelala chief priests of both the Ilaje and Ijaw-Apoi respectively. Their importance to Ayelala's deification cannot be overemphasized. This is because of the primacy given to their names, both of which are individually mentioned first as part of the praise chants in the process of appeasing the deity. This praise chants are also followed by a popular song, "Ayelala igbokoko, máa jẹ ki ayé bàjé o," meaning "Ayelala the great one, do not allow the world to perish." 58 This song, worshippers believe, helps to keep the world safe by both afflicting the wicked and thus, deterring others who are likely toe the same destructive path. Many praise chants, incantations and songs relating to Ayelala are restricted to initiates and also contain powerful meanings that refer to powers beyond the ordinary. ${ }^{59}$

Seeing the efficacy of Ayelala's powers, other neighboring and distant communities such as Ikaleland were quickly attracted to the goddess and infused it as part of their traditional deity. For the Ikale, Ayelala became one of the most prominent deities, with adherents cutting across the town. ${ }^{60}$ People in dispute, and especially those who had travelled from afar, were made to swear by the deity to resolve the issue, with full confidence in her powers to destroy any

57. O. O. Okpeh, "Patterns and Dynamics of Inter-Group Relations in Nigeria, 18001900 AD," Journal of the Historical Society of Nigeria, 17 (2007/2008): 127.

58. Interview with High Priest Agba Oye Akinbuwa, Idepe, Okitipupa. August 27, 2016.

59. S. A. Oriloye, 'Contents and Features of Yoruba Incantatory Poetry', Journal of Communication and Culture 1, no. 1 and 2 (2009): 33.

60. Ogen, “The Ikale of South-Eastern Yorubaland," 329. 
perjurer. ${ }^{61}$ Ikale's attraction to Ayelala, for instance, was hinged on the deity's ability to protect her socio-economic foundation. Eben Sheba, while examining the ubiquitous impact of Ayelala within the context of the deity's role in performing socio-judicial functions in Ikaleland, explained that Kukubaku, a non-communication symbol of Ayelala, was mounted on farmlands, personal possessions and market wares to secure them and at the same time, ensure good behavior. Its presence helped to frighten people of the deity, and thus to deter them from fiddling with, or declaring possession of, another's belongings. ${ }^{62}$ In this way, the worship of Ayelala supported the honest conduct of trade. ${ }^{63}$ Tellingly, before the incursion of colonial rule, the Ilaje, Ijaw-Apoi and people of Old Ikale Division generally were held in high regard for their acts of honesty and rectitude. ${ }^{64}$ From the economic point of view, therefore, Ayelala served as a force of order and cohesion. As the deity guaranteed mutual trust, Ayelala's presence helped to deepen inter-group relations between the Ikale and Ilaje, ${ }^{65}$ and by extension, other groups as well.

Despite the availability of means of settling disputes in pre-colonial times, these sometimes took a very long and arduous process. In actual fact, a good number of these disputes fail to accord justice to the injured party since aspects of conflict resolution are held in a 'confidential forum' which gives pre-eminence to social order rather than providing actual solution to individual grievance. ${ }^{66}$ With Ayelala's ascendance, swift justice was sought and dispensed instantaneously, abandoning, as a consequence, some of the earlier traditional means of settling disputes.

At the communal level, what appeared to be a common grievance brought before Ayelala was petty crime. However, we learnt in Ikale community and from interviews conducted elsewhere that cases of sexual offences did not only top the list but were so high that it represented the most reported case of societal anomaly put before Ayelala. Ayelala, as our informants noted, abhors sexual infractions and is very quick to dispense justice on this particular transgression. This is reminiscent of Keko's ignominious action that paved the way

61. Ibid.

62. E. Sheba, "Aale: A Deterrent Symbol and Communication Device Among the Ikale Yoruba of Nigeria," Ife: Journal of the Institute of Cultural Studies, 7 (1999): 10-17.

63. Ogen, "The Ikale of South-Eastern Yorubaland," 330.

64. Fafeyiwa, The History of Ayelala, 9; Awolalu, Yoruba Beliefs and Sacrificial Rites, 44.

65. Akinbi, "The Social, Economic and Political Relationship between the Ikale and Ilaje," 39 and 46.

66. M. Gluckman, Custom and Conflict in Africa (Oxford: Basil Blackwell, 1965), 94-95; O. Olagunju, "Traditional African Dispute Resolution (TADR) Mechanisms," November 15, 2014, http://www.linkedin.com/pulse/20141115083304-106263112-traditional-african-dispute-resolution-tadr-mechanisms. 
for Ayelala's vicarious atonement to which communal peace was finally restored. We were, nevertheless, informed that since Ayelala was a woman with the characteristic trappings of jealousy, she was most likely to be quick in her response to the cry of a fellow woman sexually offended by a man, for example through molestation or rape. ${ }^{67}$ Based on this, many communities were quick to unite against not only criminality but most importantly all forms of sexual offences.

Over the past decades, several communities outside of the Ikale, Ilaje and Ijaw-Apoi area are reputed to have adopted the deity. Ayelala's fame and power as an arbiter of swift justice has encouraged many to procure her emblem for the sake of protection against harm from potential rivals. This is done by providing the sacrificial items mentioned in the early part of this study, all of which are divided and shared equally between the Ijaw-Apoi and Ilaje priests. Having gone through the rites and full initiation which comprise the affirmation of truth in Ayelala, an emblem is thereafter presented, after which the initiate is required to establish a shrine in his abode. ${ }^{68}$ Through this, a locale of the Ayelala deity, and by extension her worship, is firmly rooted.

Chief Godwin admitted that having concluded his initiation in major communities such as Irele, Iyasan, Ijosun, Akotogbo, all in Irele LGA of Ondo State, he received his priestly emblem, after which he personally brought Ayelala worship to Oluku near Benin in $1981 .{ }^{69}$ Alhaji Musa similarly informed us that he was handed the emblem about twenty-five years back by a neighbour who had earlier been initiated among the Ilaje and Ijaw-Apoi. Like Chief Godwin, he strengthened the deity's worship in the Ijebu town of Ogbere. Thus, while initiation is mostly sought and acquired from the core area (Ilaje and IjawApoi), opportunities abound for those who wish to benefit from the deity's power elsewhere. The new places of Ayelala worship are linked to the core areas both through shared worship, and through the shared benefit from the deity's enforcement of morality.

\section{Conclusion}

Our study has expressly examined Ayelala worship in selected communities in coastal Yorubaland and described how this deity came to exist. We suggest-

67. Interview with Otunba Johnson Gbemisola, Ifa Priest, No. 8, Ifelodun Street, Off Rainbow Road, Ondo. October 14, 2016.

68. Interview with Alhaji Dauda Musa, September 27, 2016. The period of full initiation could take as much as nine to ten years.

69. Chief Godwin, Ayelala chief priest, Ayelala headquarters, Oluku, Benin, October $10,2016$. 
ed that the deity's power derives from the existence of boundaries and difference, but is used to ensure close adherence to the existing categories of the moral order, both for individuals and their families, and for lager groups. This phenomenon reflects Ayelala's striking power and potency, which is also seen in the reverence extended to her. Though doubts have been raised over the authenticity of the deity in recent times as monotheistic faiths appear to have taken hold in most coastal communities, ${ }^{70}$ and since Ayelala priests are frequently disparaged today for their extortionist practices and fraudulent appropriation of victims' wealth, ${ }^{71}$ many people, including Christians and Muslims, confirm that Ayelala exist and that her punitive inflictions are genuine and never in doubt. ${ }^{72}$

Our study illustrates that Ayelala's powers position the deity as a potent tool for intergroup relations. As noted earlier, even though Ayelala was originally linked only to the Ilaje and Ijaw-Apoi, its worship is also associated with other sub-groups. This is particularly interesting in the case of Benin and Ijebu, which have at times been at odds with the groups in the core areas of worship. However, as in the original sacrifice of Ayelala, the deity's ability to manage personal and group behavior clearly allows it to expand its followership further across political boundaries. Especially in areas where the lust for power or wealth has led to conflict, the shared worship of Ayelala can help to resolve such problems.

70. See F. Larr, Africa's Diabolical Entrapment: Exploring the Negative Impact of Christianity, Superstition and Witchcraft on Psychological, Structural and Scientific Growth in Black Africa! (Indianapolis: AuthorHouse, 2013), 90-103; S. Njokede, "Ayelala God Killed Looters of Oba Market-Fire in Benin City," http://www.saharareporters.com/2010/10/30/ayelalagod-killed-looters-oba-market-fire-benin-city, October 30, 2010.

71. Omosule, Ayelala: "The Truth of the Matter," 2. See also, O. Ayelala Telewa, "Changing Times for a Once Powerful, Feared Ondo Deity," National Mirror, October 12, 2014.

72. Interviews with Chief Omo-Osagie Utetemegiabi, Obadolagbonyi of Benin, Palace of the Oba of Benin and Chief Godwin, Ayelala chief priest, Oluku, Benin, both October 10, 2016; Interviews with Mary Isibor, civil servant, Benin City, October 22, 2016 and Onwaneben Evelyn, skills acquisition officer, BDPE, Ugbowo, Benin City, October 22, 2016; Interview with Job Kikelomo, indigene of Ijaw-Apoi and student, Adeyemi College of Education, Ondo, October 24, 2016. 